\title{
Internal determinants of university student employability. Construction and validation of scales
}

\author{
Caballero, Gloria ${ }^{\text {; }}$ Álvarez, Paula ${ }^{a}$; López-Miguens, M.J. ${ }^{\text {b }}$ \\ ${ }^{a}$ Department of Business Organization, University of Vigo, Spain. ${ }^{b}$ Research group I-mark. \\ University of Vigo, Spain.
}

\begin{abstract}
One of the challenges faced by European universities today is to ensure that their graduates find employment in line with their attributes. Graduate employability depends, among other factors, on many internal determinants in individuals. However, there is no consensus on how to measure them, and the scales developed to date have not been properly validated. The purpose of this paper is to construct and validate, at confirmatory level, a set of instruments for measuring the internal determinants of graduate employability. The results, based on a sample of 816 students, show the structure of the scales resulting from checking content validity, dimensionality, reliability, and convergent, discriminant and nomological validity.
\end{abstract}

Keywords: employability, internal determinants, university, scales, psychometric properties. 


\section{Introduction}

Internal determinants of employability can differentiate graduates and make them more employable, preventing them from facing the dilemma of an unsuitable job or none at all. There have been few studies on the internal determinants of employability, with most of them considering just one determinant, and just a few considering several internal determinants together (Chou and Shen, 2012; Dacre and Sewell, 2007; Dacre et al., 2014). Moreover, regarding scales for measuring such determinants, very few of them use confirmatory tests for validation and. when they do, they do not perform a full analysis of their psychometric properties (e.g. Dacre et al., 2014), or their samples are small (e.g. De Guzmán and Choi, 2013; Yusof et al., 2012).

This study proposes a set of scales that have been validated at confirmatory level for measuring the internal determinants of employability. It has several strengths. From a theoretical point of view, it presents an updated review of the literature on the internal determinants of employability and scales for measuring them. From an empirical point of view, the following scales have been validated at confirmatory level, translated and/or adapted from prior research on the internal determinants of employability - self-confidence, ambition, competencies, training and self-efficacy for job searching.

The paper is structured as follows. After this introduction, we describe the theoretical framework for the internal determinants of employability. We then explain the methodology followed, and develop and validate the measurement scales. Finally, we draw conclusions.

\section{Theoretical background}

Based on the review of the literature, in this study employability is considered as the capacity for obtaining and keeping a job or obtaining a new one if required (Hillage and Pollard, 1998). However, a more thorough definition considers that there are certain external or contextual and internal determinants that affect it (Hernández-Fernaud et al., 2011; Hillage and Pollard, 1998; Gamboa et al., 2007; Rothwell et al, 2008; Rothwell et al., 2009; Tymon, 2013) and which should therefore be considered when explaining employability (Fugate et al., 2004).

Although employability and its factors have received considerable attention in the literature (Dacre et al., 2014), as stated by Finch et al. (2013: 682), "much of the research into employability factors is theoretical".

Internal determinants refer to the perception that individuals have on themselves, that is, on their internal attributes (Rothwell et al., 2008). In this research we consider self-confidence, 
ambition, skills, training and self-efficacy for job searching. All of these have been shown to be key components in the development of employability (Dacre et al., 2014; Dacre and Sewell, 2007), but most of them have not been used together in the literature. Most of the studies use a single internal variable.

Self-confidence. Self-confidence refers to the way in which individuals project their capacities and abilities in their environment and use them successfully when searching for and obtaining a job (Dacre and Sewell, 2007; Rothwell et al., 2008; Rothwell et al., 2009; Wittekind et al., 2010).

Ambition. Ambition measures individuals' perception of success for a future career or for future job searching (Rothwell et al., 2009). Rothwell et al. (2008) state that ambition affects the perception of employability because the fact that students are not yet workers explains why ambition is a necessary indicator of the perception of success in the future.

Competencies. Competencies cover the knowledge, values, attitudes, abilities and skills needed to obtain, keep and perform well in a job (Conchado and Carot. 2013; De Guzman and Choi. 2013). In today's society, graduates have to have the skills required by employers (Freire et al., 2011; Suárez, 2014). Since this research covers students from all fields of study, we focus only on general competencies. These are the ones that are in most demand from employers because they complement the specific competencies covered by the course of study (Freire et al., 2011).

Training. Training refers to academic performance, that is, the results and grades obtained by students and their satisfaction with them (Dacre et al., 2014; Rothwell et al., 2008), as well as their future commitment to acquire greater knowledge (Van der Heijde and Van der Heijden, 2006). Both academic performance (Dacre et al., 2014; Hillage and Pollard, 1998; Rothwell et al., 2008) and continuous learning and improved learning (Van der Heijde and Van der Heijden, 2006) are considered in studies of graduate employability (Dacre and Sewell. 2007; Rothwell et al., 2008, 2009) and workers' career development (Rothwell and Arnold. 2007).

Self-efficacy for job searching. Finally, self-efficacy for job searching refers to the individual's confidence and motivation in a specific situation, such as job searching (Chou and Shen, 2012; Dacre and Sewell, 2007; Hernández-Fernaud et al., 2011; Van der Heijde and Van der Heijden, 2006). Some authors conclude that it is a good predictor of success (Wittekind et al., 2010), especially for students (Chou and Shen, 2012). 


\section{Methodology}

The population studied was made up of 6,242 students registered during the 2014-2015 academic year in the last year of a graduate course at a Spanish university. A probabilistic method with proportional stratification was used to select the sample, considering the stratification variable to be the percentage of last-year students registered in this university in each of the five fields of study laid down by the Spanish Ministry of Education, Culture and Sport, that is, Arts and Humanities, Science, Social and Legal Science, Engineering and Architecture, and Health Science. The information was compiled between April and June 2015 from personal interviews. The final sample, after data cleansing - processing of missing values, analysis of outliers and normality tests - amounted to 816 students, representing a response rate of $13.07 \%$.

\section{Scales of measurement}

\subsection{Generation of items}

In order to build a valid tool for measuring each of the internal determinants of employability, a thorough review of the specific literature was performed. The initial proposal for the number of items for each variable and the studies on which they are based is given in Table 1. All the variables were rated using 7-point Likert scales. A sample of the items of each variable is: self-confidence, "I believe I could hold any job providing that my skills and experience are needed for it"; ambition, "I believe it is urgent for me to progress in my career"; competencies, "I can convince others of my worth"; training, "I am satisfied with my academic performance so far"; self-efficacy for job searching, "I know where to find information about the jobs I am interested in" and employability, "I am sure I shall find work easily if I start looking".

Table 1. Proposal for scales to measure the internal determinants of employability

\begin{tabular}{l|l}
\hline \multicolumn{1}{c|}{ Variable (number of items) } & \multicolumn{1}{c}{ Author(s) } \\
\hline Self-confidence (7 items) & Rothwell et al. (2008) \\
Ambition (5 items) & Rothwell et al. (2008) \\
Competencies (34 items) & $\begin{array}{l}\text { Andrews and Higson (2008), Conchado } \\
\text { and Carot (2013) and Dacre et al. (2014) }\end{array}$ \\
Training (8 items) & $\begin{array}{l}\text { Rothwell et al. (2008) } \\
\text { Self-efficacy for job searching (13 } \\
\text { items) }\end{array}$ \\
Employability (3 items) & Fernaud et al. (2014) and Hernández- \\
\hline
\end{tabular}


Transcultural adaptation of the items was then performed (Más and Escribá, 1998; RosMorente et al., 2011), with conceptual rather than literal translation (Gutiérrez et al., 2007) and adaptation to the culture and routine of the respondents (Mirtea et al., 2008). This selection was then reviewed critically by five experts in higher education.

\subsection{Validation of the measurement scales}

We validated the scales proposed by analysing their psychometric properties, that is, content validity, unidimensionality, reliability and convergent, discriminant and nomological validity.

The content validity of the scales was guaranteed as follows: (1) by identifying the items and dimensions for each of them based on a thorough review of the literature; (2) by having the appropriateness, adaptation and/or translation of the items and dimensions checked by a group of experts, and (3) by guaranteeing, during the process of re-specification of the measurement models, that the items remaining in the model conceptually covered the full extent of each variable.

To study the unidimensionality of the scales, a exploratory factor analysis (EFA) was carried out. Previously, we considered whether factor analysis was appropriate for analysing the data. For this purpose, we checked that the determinant for the correlations matrix for each scale was close to 0 and that the result of the KMO test was close to 1 (Levy and Varela. 2003). Then EFA was performed using Principal Component analysis with Varimax rotation as the extraction method, finding that the factor loadings in the rotated component matrix were, depending on the sample size, above 0.3. In order to determine the number of dimensions in each scale, we required eigenvalues above 1 and that the percentage of explained variance was close to $60 \%$. Study of the communalities obtained, which in all cases reached values above or very close to 0.50 (Hair et al., 1999), indicated that all the items helped explain the factor solution obtained.

Scale reliability was analysed using 4 tests: (1) Cronbach's Alpha, (2) total item correlation, (3) composite reliability (CR), and (4) average variance extracted (AVE). The value for Cronbach's alpha was above 0.7 (Nunnally, 1978), fluctuating between 0.745 for the training scale and 0.935 for the ambition scale. In all cases, correlations between the items on each scale was in excess of 0.5 , and for composite reliability and average variance extracted the results were above or very close to 0.7 (Hair et al., 1999; Luque, 2000) and 0.5 (Hair et al., 1999; Sharma, 1996), respectively. It can therefore be deduced that there is internal consistency and high reliability in all the scales.

The convergent validity of the scales was studied by reviewing the value of the factor loadings of all the items and their degree of significance. All the loadings were significant and exceeded 0.5 (Hildebrandt, 1987), proving convergent validity. 
Discriminant validity was analysed using 2 tests to check that: (1) correlations between the variables were not above 0.8 (Hair et al., 1999), and (2) the square of the correlation between each pair of variables was not above the average variance extracted obtained for each of these variables (Fornell and Larcker, 1981). The results show that there is discriminant validity.

We performed 2 tests to study nomological validation: (1) correlations between all the variables in the study and their significance (Sharma and Chan. 2011), and (2) the relations between these variables and the employability variable because, as explained in the literature review, they all turned out to be antecedents of employability. According to the results of the first test, all the variables were mutually and significantly correlated at the 0.01 level. For the second test, first we validated the employability scale, measured by 3 items adapted from Wittekind et al. (2010). We then checked that all the variables are antecedents of employability, and found that the strongest relations were with the variables for self-confidence, competencies and self-efficacy for job searching, and the weakest were with ambition and training. We therefore deduced that there is nomological validity in all the scales.

\section{Conclusions}

The main purpose of this study was to validate a set of scales for measuring the internal determinants of the employability of university students, and it was motivated by the lack of validated scales at confirmatory level (Dacre et al.. 2014; Yusof et al.. 2012). As internal determinants of employability, it identifies self-confidence, ambition, competencies, training and self-efficacy for job searching. The analyses performed on these scales regarding content validity, dimensionality, reliability, and convergent, discriminant and nomological validity show satisfactory results and allow us to conclude that the variables of self-confidence and ambition are unidimensional and the others are multidimensional. Competencies were measured on the basis of five dimensions relating to the degree of adaptability of students to different situations, their efficiency in performing tasks, their negotiating skills, their emotions and their form of expression. Training was structured in two dimensions - students' performance during their course of study, and their commitment to continuous training. Self-efficacy for job searching was measured using two dimensions - knowledge about the desired job, and predisposition in selection processes.

This study should therefore be of use for three groups. Firstly, it amounts to important progress for future research in that it proposes a set of scales for measuring the internal determinants of employability and validates it at confirmatory level. Secondly, students are offered a tool that may help them to focus their efforts on improving or developing the 
attributes that might make them more employable. Finally, it enables universities to identify activities that will help develop the attributes that students need.

\section{References}

Chou, C. M., \& Shen, C. H. (2012). Factors influencing employability self-efficacy of engineering students in Taiwan. International Journal of Engineering Practical Research, 1(1), 10-14.

Conchado, A., \& Carot, J. M. (2013). Puntos fuertes y débiles en la formación por competencias según los graduados universitarios españoles. Revista de Docencia Universitaria, 11(1), 429-446.

Dacre, P. L., \& Sewell, P.J. (2007). The key to employability: developing a practical model of graduate employability. Education + Training, 49(4), 277-289.

Dacre, P. L., Qualter, P., \& Sewell, P.J. (2014). Exploring the factor structure of the Career EDG Employability development profile. Education + Training, 56(4), 303-313.

De Guzman, A. B., \& Choi, K. O. (2013). The relations of employability skills to career adaptability among technical school students. Journal of Vocational Behavior, 82(3), 199-207.

Finch, D.J., Hamilton, L.K., Baldwin, R., \& Zehner, M. (2013). An exploratory study of factors affecting undergraduate employability. Education + Training, 55(7), 681-704.

Freire Seoane, M. J., Teijeiro Alvarez, M., \& Pais Montes, C. (2011). Políticas educativas y empleabilidad: ¿cuáles son las competencias más influyentes?. Education Policy Analysis Archives, 19(28), 1-24.

Fugate, M., Kinicki, A. J., \& Ashforth, B. E. (2004). Employability: A psycho-social construct, its dimensions, and applications. Journal of Vocational Behavior, 65, 14-38.

Gamboa, J. P., Lerin, F. J. G., Botella, P. R., \& Silla, J. M. P. (2007). La empleabilidad y la iniciativa personal como antecedentes de la satisfacción laboral. Working papers: Serie EC (Instituto Valenciano de Investigaciones Económicas), (1), 1.

Gutiérrez, C., Veloza, M. M., Moreno, M. E., Durán, M. M., López, C., \& Crespo, O. (2007). Validez y confiabilidad de la versión en español del instrumento "Escala de medición del proceso de afrontamiento y adaptación" de Callista Roy. Revista Aquichan, 7(1), 54-63.

Hair, J.F., Anderson, R.E., Tatham, R.L., \& Black, W.C. (1999). Análisis Multivariante. Spain: Prentice Hall.

Hernández-Fernaud, E., Ramos-Sapena, Y., Negrín, F., Ruiz-de la Rosa, C., \& Hernández, B. (2011). Empleabilidad percibida y autoeficacia para la búsqueda de empleo en universitarios. Revista de Psicología del Trabajo y de las Organizaciones, 27(2), 131142.

Hildebrandt, L. (1987). Consumer retail satisfaction in rural areas: A reanalysis of survey data. Journal of Economic Psychology, 8, 19-42.

Hillage, J., \& Pollard, E. (1998). Employability: Developing a framework for policy analysis. London: Department for Education and Employment. 
Lévy, J. P., \& Varela, J. (2003). Análisis multivariable para las ciencias sociales. Spain: Pearson Educación, S.A.

Luque, T. (2000). Técnicas de análisis de datos en investigación de mercados. Spain: Pirámide.

Más, R., \& Escribá, V. (1998). La versión castellana de la escala "The Nursing Stress Scale". Proceso de adaptación transcultural. Revista Española de Salud Pública, 72(6), 529-538.

Mirtea, J., Herrans, L. L., Pons, J., Matías-Carrelo, L., Medina, G., \& Rodríguez, M. (2008). Proceso de traducción y adaptación para Puerto Rico de la Wechsler Adult Intelligence Scale-III: Escala de Inteligencia Wechsler para Adultos, Versión III (EIWA-III). Revista Puertorriqueña de Psicología, 19, 58-74.

Nunnally, J.C. (1978). Psychometric theory, 2nd ed. New York: McGraw Hill.

Ros-Morente, A.,Vilagrà-Ruiz, R., Rodriguez-Hansen, G., Wigman, J. H., \& BarrantesVidal, N. (2011). Proceso de adaptación al castellano de la Escala de Evaluación Comunitaria de Experiencias Psíquicas (CAPE). Actas Españolas de Psiquiatría, 39(2), 95-105.

Rothwell, A., Herbert, I., \& Rothwell, F. (2008). Self-perceived employability: Construction and initial validation of a scale for university students. Journal of Vocational Behavior, 73, 1-12.

Rothwell, A., Jewell, S., \& Hardie, M. (2009). Self-perceived employability: Investigating the responses of post-graduate students. Journal of Vocational Behavior, 75(2), 152161.

Sharma, P., \& Chan, R. Y. (2011). Counterfeit proneness: Conceptualisation and scale development. Journal of Marketing Management, 27(5-6), 602-626.

Suárez Lantarón, B. (2014). La universidad española ante la empleabilidad de sus graduados: estrategias para su mejora. The spanish universities and the employability of its graduates: the strategies to improve it. REOP-Revista Española de Orientación y Psicopedagogía, 25(2), 90-110.

Tymon, A. (2013). The student perspective on employability. Studies in Higher Education, 38(6), 841-856.

Van der Heijden, C., \& Van der Heijden B. (2006). A competence-based and multidimensional operationalization and measurement of employability. Human Resource Management, 45, 449-476.

Wittekind, A., Raeder, S., \& Grote, G. (2010). A longitudinal study of determinants of perceived employability. Journal of Organizational Behavior, 31, 566-586.

Yusof, H. M., Mustapha, R., Mohamad, S. A., \& Bunian, M. S. (2012). Measurement model of employability skills using confirmatory factor analysis. Procedia-Social and Behavioral Sciences, 56, 348-356. 